\title{
Gregor Mendel and the Seven Genes (1)
}

\author{
Yoshio Tateno $^{1, *}$ \\ ${ }^{1}$ School of New Biology, Daegu Gyeongbuk Institute of Science and Technology (DGIST), Hyeonpung, Dalseong, Daegu, Korea
}

Subject areas; General

Author contribution; Y.T. wrote this article

*Correspondence and requests for materials should be addressed to Y.T. (yt.tateno@gmail. com)

Editor; Hong Gil Nam, Daegu Gyeongbuk Institute of Science \&t Technology, Korea

Received October 22, 2013

Accepted October 30, 2013

Published October 31, 2013

Citation; Tateno, Y. Gregor Mendel and the Seven Genes (1). IBC 2013, 5:7, 1-3. doi: 10.4051/ibc.2013.5.4.0007

Competing interest; All authors declare no financial or personal conflict that could inappropriately bias their experiments or writing. (c) Tateno Y.This is an Open Access article distributed under the terms of the Creative Commons Attribution Non-Commercial License (http://creativecommons.org/licenses/by-nc/3.0) which permits unrestricted non-commercial use, distribution, and reproduction in any medium, provided the original work is properly cited.

\section{SYNOPSIS}

This essay describes $\mathrm{G}$. Mendel's life and his law of inheritance. He was born in a poor family in 1822 in a hamlet in Czechs. At that time the Habsburg Empire dominated over the East Europe in which Vienna was the capital. Vienna had thus been the center of culture and learning, and attracted many artists and scholars such as W. Mozart (17561791), L. Beethoven (1770-1827), C. Doppler (1803-1853), S. Freud (1856-1939), G. Mahler (1860-1911), G. Klimt (1862-1918) and E. Schiele (1890-1918). Beethoven came to Vienna to learn from Mozart. Klimt was influence by Schilele. When Mahler consulted Freud about his mental problem, Freud said to him "Your mental condition was not normal, but the condition made you creative. So, do not worry too much about it." Like that, there were many interactions among them, and Mendel was no exception.

Though Mendel was poor, he was fortunate in his education and scientific research, because he could have excellent supporters in his family and out of it. He learned mathematics and physics at Vienna University under the guidance of C. Doppler. He was not totally alone when he discovered his law of inheritance. It may not be true either that his law was neglected and rediscovered in the year of 1900. As his one and only paper indicates, he was one of the earliest interdisciplinary scientists.

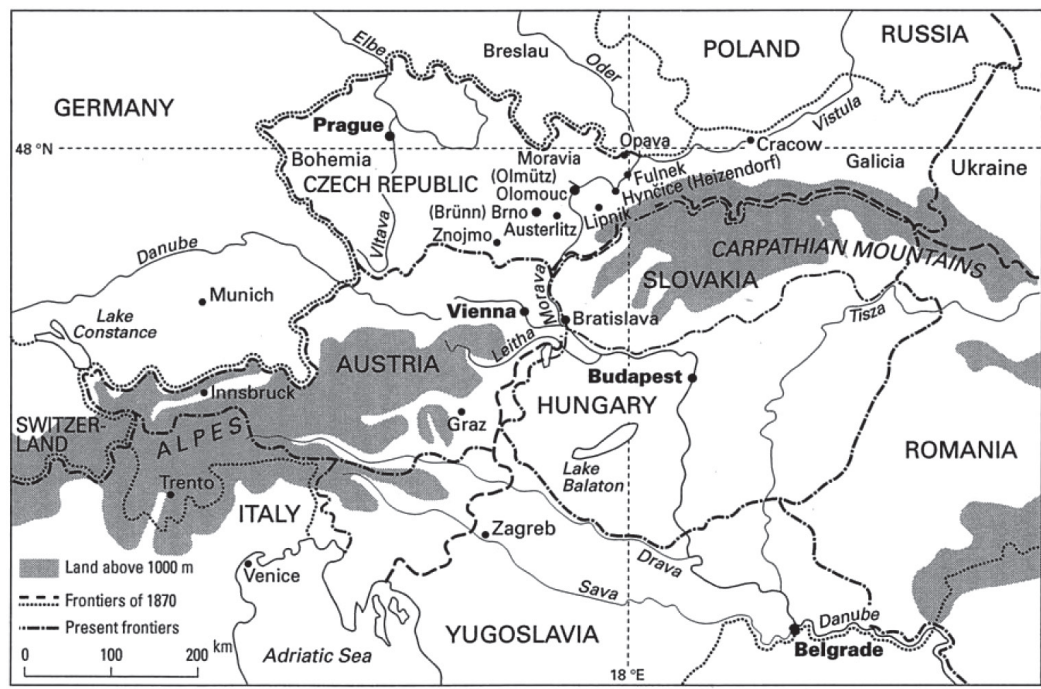

Key Words: G. Mendel; interdisciplinary scientist; Mendel's law; hybridization experiments; seven genes 
It is a pity that even biology students nowadays do not know about Mendel's law of inheritance. That is my motivation to write a small essay about him and his law here.

Johann Mendel was born on July 22, 1822 as only son of a poor family in a small village in of Hyncice in Czechs (see the map in Figure 1 for the location). In those days the Habsburg Empire dominated and governed also Czechs. His mother, Rosine Schwirtlich, was a daughter of a gardener, and apparently attracted her son to growing plants. Although his family was poor, Johann could learn at a local gymnasium (like a junior high-school) for six years. He was already an excellent student there. During this period he was interested in meteorology, because he observed that agricultural harvests were influenced so much by weather conditions. He also wrote a poem at the gymnasium that expressed the power of the printed word that made possible for children in those days to learn many subjects. In the poem he also revealed his conviction that science would resolve many problems humans suffered from.

In 1840 he graduated from the gymnasium, and thought about the way to go further to studying, and finally decided to enter the Philosophy Institute of Olomouc (Figure 1) tearing himself away from his father's wish to succeed him to be a farmer. He was determined to study science without listening to his father. In the Institute he studied for two years to enter a university, meanwhile his elder sister married and took over her father. The sister strongly helped Johann, whose efforts were always unsuccessful, because of a lack of friends and references. He had been grateful to his sister in the rest of his life, and helped her sons in their studies. Perhaps, he was a shy and stubborn person.

Johann entered Olomouc University (Figure 1) in 1842 where he mainly took the courses of mathematics, physics and logic. Among them physics was taught by Prof. F. Franz who greatly influenced Johann in forming his future career. However, he

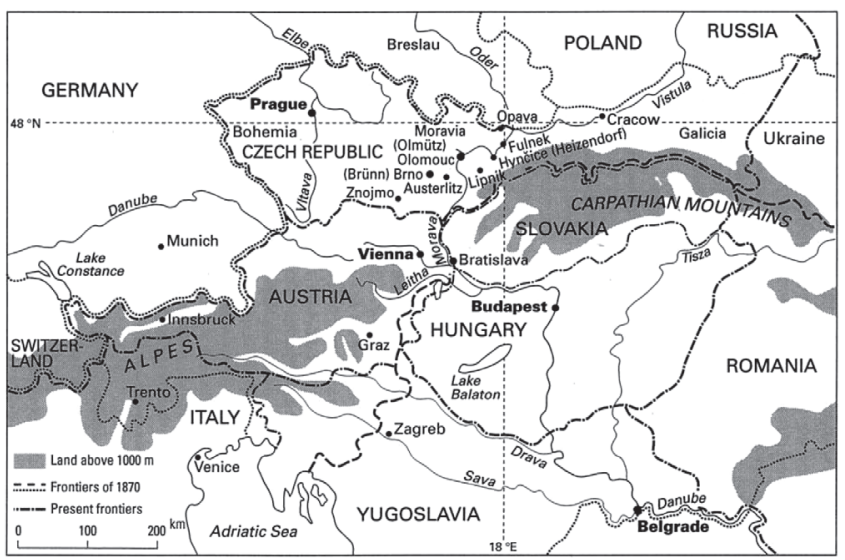

Figure 1. A map of Northeast Europe in the 19th century ${ }^{1}$ (The map is copied from Figure 2.1 of reference 1.). could not pursue his study in the University owing to a lack of financial support. Then, in 1843 he was admitted to the Augustinian Monastery of St. Thomas in Brno (Figure 1). For his application Prof. Franz wrote a recommendation letter to the Augustinian abbot, C. F. Napp, that greatly helped Johann to be admitted. The letter says "during the two years course in philosophy J. Mendel wrote the most exceptional report, ......, in my own branch he was almost the best.... Though the candidate's Czech was poor, he was prepared to work on it..." Johann was given the name of "Gregor", as he began the novitiate in the Monastery. His well-known first name is not his birth name but the professional one.

Napp was a scientist as well, and published many papers about growing grapes and other fruits. One of the important activities at a monastery was to brew wine to sell. He was later elected as the president of the Society of Natural Science Brno. It is also noteworthy that he one time explained to sheep breeders that the problem of heredity was a subject for physiological research. He asked many scholars to visit and teach mathematics, physics, logic, agriculture, music and others at the Monastery. The Monastery functioned also as a school in those days. In the Monastery Gregor soon met A. Keller, who was a member of the Agricultural Society, Brno, and interested in the breeding of new varieties of grapes and other fruits. Fortunately, from the beginning of his career Gregor was acquainted with an expert on agriculture, and began to cultivate a botanical garden there and devoted himself to a study of natural science in his spare time. The environments of the Monastery greatly helped Gregor to pursue his study.

In 1848 Napp sent Gregor to study physics under the guidance of Christian Doppler in the Vienna University. Doppler is well known now for formulating the phenomenon called later as the Doppler effect in 1842. It is about the change in frequency of the sound from a moving vehicle like an ambulance siren. When the vehicle is coming toward the observer, the frequency is higher than the normal one, and lower when it is passing away. His formula was proved correct in 1845 by Dutch meteorologist C. Buys-Ballot (1817-1890) with the help of a trumpeter on a train and a person with absolute pitch.

More importantly to Gregor, Doppler wrote and published a textbook of arithmetic and algebra in which he explained the combination theory and probability theory. Reading the textbook Gregor learned those theories, which would greatly help him later with performing the hybridization experiments of pea and interpreting the results. His knowledge about mathematics certainly helped to understand the textbook. He did not restrict himself to the subjects to learn. One day when he attended the meeting of the Society of Natural Science Brno, he listened to the poem that a physician called C. Alle recited. It is as follows, 
If matters act upon matters, a force develops,

To eavesdrop on the laws of nature and their explanation Is what science is aiming for.

\section{REFERENCE}

1. Orel, V. e. (1996). Gregor Mendel : the first geneticist. 1st Edition. Oxford ; New York: Oxford University Press. 